\title{
Structural and Antimicrobial Studies of Coordination Compounds of Phenylalanine and Glycine
}

\author{
Aiyelabola Temitayo (Corresponding author) \\ Department of Chemistry, Faculty of Science Obafemi Awolowo University \\ Ile-Ife, Osun-State, Nigeria \\ E-mail: tt1haye@yahoo.com \\ Ojo Isaac \\ Department of Chemistry, Faculty of Science Obafemi Awolowo University \\ Ile-Ife, Osun-State, Nigeria \\ E-mail: Ojo_isaac99@hotmail.com \\ Akinkunmi Olugbenga \\ Department of Pharmaceutics, Faculty of Pharmacy Obafemi Awolowo University \\ Ile-Ife, Osun-State, Nigeria \\ E-mail: eoakinmi@oauife.edu.ng
}

$\begin{array}{ll}\text { Received: December 21, } 2011 & \text { Accepted: January 6, } 2012 \quad \text { Published: April 1, } 2012 \\ \text { doi:10.5539/ijc.v4n2p49 } & \text { URL: http://dx.doi.org/10.5539/ijc.v4n2p49 }\end{array}$

\begin{abstract}
Coordination compounds of glycine and phenylalanine were synthesized, characterized using electronic and infrared spectroscopy, magnetic susceptibility measurement and mass spectrometry. The ligands coordinated to the metal in a bidentate fashion using $\mathrm{N}$ and $\mathrm{O}$ donor atoms. Square planar geometry is proposed for the Mn(II), $\mathrm{Co}(\mathrm{II}), \mathrm{Ni}(\mathrm{II})$ and $\mathrm{Cu}(\mathrm{II})$ complexes based on the results obtained from their characterization. Tetrahedral geometry is however proposed the $\mathrm{Cd}(\mathrm{II})$ complexes. The in-vitro biological effect of the synthesized compounds was investigated. The compounds were tested against three gram-negative bacteria, E.coli, $P$. aeruginosa, $P$. vulgaris, three gram positive bactria, S. aureus, B. subtilis, MRSA and a fungus C. Albicans. A comparative study of the zones of inhibition observed for the ligand and coordinated synthesized compounds indicated that the synthesized compounds, in some cases, showed higher zones of inhibition than that of the free ligands. It is therefore suggested that increasing the number of chelate rings may increase the lipophilicity of the coordinated complex and therefore its antimicrobial activity.
\end{abstract}

Keywords: Phenyalanine, Glycine, Lipophilicity, Antimicrobial agent, Coordination, Gram-Positve, Gram-negative

\section{Introduction}

The study of coordination compounds has received much attention in recent years. This interest was generated by the discovery of the anti-bacterial, -fungal and -cancer activities of several coordination compounds. As a result, studies have been carried out on the structure and chemical behavior of several metal complexes (Chohan et al., 2006). Various in-vivo studies have shown that biologically active compounds become more bacteriostatic and carcinostatic upon chelation (Chohan et al., 2006; Husseiny et al., 2008). Amino acids, which are also components of proteins, offer excellent ligands for binding to metal ions (Zhang \& Lippard, 2003; Kostova, 2006). The properties of coordination compounds are influenced to a considerable extent by the nature and the oxidation state of the central metal atom. A method of studying this influence is by comparing the compounds formed by a series of metal atoms in a given oxidation state with a particular ligand (Komiyama et al., 2008). 
Although coordination compounds of amino acids, such as histidine (Nomiya et al., 2000), arginine, glutamic acid (Legler et al., 2001) have been synthesized and their antimicrobial properties studied, little attention has been focused on hydrophobic amino acids, such as phenylalanine. Chelation of bulky ligands to metal cations reduces the polarity of the ion. Due to the glycolipophilic nature of the cell wall, an increase in the lipophilicity of a coordination compound enhances its ability to penetrate bacterial cell membrane. This concept has been applied to the molecular design of coordination complexes of phenylalanine (1). Phenylalanine is a hydrophobic amino acid with a bulky benzyl $\mathrm{R}$ side chain. The results obtained are then compared with that of similar coordination complexes of glycine (2), (the simplest amino acid).

This paper reports the synthesis and characterization of coordination compounds of manganese (Mn), cobalt (Co), copper $(\mathrm{Cu})$, cadmium $(\mathrm{Cd})$ and nickel $(\mathrm{Ni})$ with phenylalanine (1) and glycine (2), metal to ligand ratio 1:2 and the evaluation of their antimicrobial activities.

\section{Materials and Methods}

\subsection{General}

All reagents and solvents used were of analytical grade. The complexes were prepared according to a modification of literature procedure (Nomiya \& Yokoyama, 2002). The infrared spectra were recorded on a Genesis II FTIR spectrophotometer in the range $450-4200 \mathrm{~cm}^{-1}$ (KBr discs). The solid reflectance electronic absorption spectra of the complexes in the range 200-1000 nm were obtained with a Genesys UV-Vis spectrophotometer. Melting points or decomposition temperatures (M.P/D.T.) was measured using open capillary tubes on a Gallenkamp (variable heater) melting point apparatus. The magnetic susceptibility for some of the complexes was measured at room temperature using a MSB-AUTO (Sherwood scientific) Gouy balance. Mass spectra were obtained with a GCT premier mass spectrometer, by direct insertion electron impact ionization with a time of flight (TOF) analyzer. The general equations for the reactions are as follows:

$$
\begin{gathered}
\mathrm{MCl}_{2}+2 \mathrm{HL} \longrightarrow \mathrm{ML}_{2}+2 \mathrm{HCl} \\
\mathrm{MSO}_{4}+2 \mathrm{HL} \longrightarrow \mathrm{ML}_{2}+\mathrm{H}_{2} \mathrm{SO}_{4}
\end{gathered}
$$

Where $\mathrm{M}=\mathrm{Co}(\mathrm{II}), \mathrm{Cu}(\mathrm{II}), \mathrm{Mn}(\mathrm{II}), \mathrm{Ni}(\mathrm{II}), \mathrm{Cd}(\mathrm{II}) ; \mathrm{L}=$ phenylalanine and glycine.

\subsection{Preparation of Coordination Complexes}

The coordination compounds were prepared by the addition of $0.01 \mathrm{M}(2.46,2.61,2.38,1.72$ and $2.11 \mathrm{~g})$ of the appropriate metal salt (manganese, cobalt, nickel, copper, and cadmium respectively) to a solution of the ligand (1) $0.02 \mathrm{M}, 3.37 \mathrm{~g}$ and (2) $0.02 \mathrm{M}, 1.52 \mathrm{~g}$. The mixture was then heated to reflux for $1 \mathrm{~h}$, using a water bath. Precipitates were formed within the refluxing time for majority of the complexes, while some required concentration on a water bath and cooling before solid products were obtained. The products obtained were filtered and washed with methanol. Products were then dried in vacuo at $60{ }^{\circ} \mathrm{C}$.

\subsection{Antimicrobial Activity using Disc Diffusion Assay}

The in vitro antimicrobial properties of the complexes were performed at the Pharmaceutics laboratory at the department of Pharmaceutics, Faculty of Pharmacy Obafemi Awolowo Univerfsity, using a modification of literature procedure (Murray et al., 1995). The strains used were Escherichia coli NCTC 8196, Pseudomonas aeruginosa ATCC 19429, Staphylococcus aureus NCTC 6571, Proteus vulgaris NCIB, Bacillus subtilis NCIB 3610 and Methicillin resistant $S$. aureus clinical isolate for bacteria and C. albicans NCYC 6 for fungi. The standard strains were from stocks of culture collections maintained in the laboratory. Bacteria were maintained on nutrient agar slants and fungi on Sabouraud Dextrose Agar slants at $4{ }^{\circ} \mathrm{C}$ and subcultured monthly. Each test agent $(20 \mathrm{mg})$ was dissolved in $1 \mathrm{ml}$ sterile distilled water boiled gently in a Bunsen flame. Discs of Whatman No 1 filter paper $(\varphi 6 \mathrm{~mm})$ were soaked with 2 drops of the test agent using a sterile Pasteur pipette and allowed to dry at room temperature.

Two colonies of a 24-hour plate culture of each organism were transferred aseptically into $10 \mathrm{ml}$ sterile distilled water in a test tube and mixed thoroughly, using an electric shaker, for uniform distribution. A sterile cotton swab was then used to spread the resulting suspension uniformly on the surface of oven-dried Mueller Hinton Agar (Oxoid) and Sabouraud Dextrose Agar plates (Sterillin) for bacteria and fungi, respectively. These were incubated for an hour at 37 and $25{ }^{\circ} \mathrm{C}$ for bacteria and fungi, respectively. Sterile forceps were used to aseptically place each of the discs on the agar plates and the plates were then refrigerated for 30 min at $4{ }^{\circ} \mathrm{C}$ following which, the inoculated plates were incubated at $37{ }^{\circ} \mathrm{C}$ for 24 hours for bacteria strains and at $25{ }^{\circ} \mathrm{C}$ for 72 hours for the fungal strain. Antimicrobial activity was evaluated by noting the zone of inhibition against the test organisms (Murray et al., 1995). 


\section{Results and Discussion}

\subsection{General}

All the complexes were sparingly soluble in general organic solvents. The melting points or decomposition temperatures are shown in Table 1, most of the complexes decomposed before melting. A square planar structure is proposed for the complexes with exception of the cadmium complexes. Based on the valence bond theory for a $d^{10}$ system, a tetrahedral geometry is proposed for the cadmium complexes. Attempts to isolate suitable crystals for single X-ray structural determination have not been successful so far.

\subsection{Electronic Spectra}

The electronic spectra data are presented in Tables 2 and 3. Analysis of the spectra was carried out by the comparison of the spectra of the complexes with that of their respective ligands. This revealed a shift in some of the bands observed in the ligand and the appearance of new bands in the visible region for the complexes.

\subsubsection{Phenylalanito Complexes}

Ligand (1) exhibited absorption bands at $196 \mathrm{~nm}\left(\lambda_{1}\right), 217 \mathrm{~nm}\left(\lambda_{2}\right)$, attributed to the $\mathrm{n} \rightarrow \pi^{*}$ and $233 \mathrm{~nm}\left(\lambda_{3}\right), 268$ $\mathrm{nm}\left(\lambda_{4}\right), \pi \rightarrow \pi^{*}$ of the carbonyl, amino and benzene ring. A shift was observed generally for all the complexes indicating coordination. The $\mathrm{Co}(\mathrm{II})$ complex exhibited a band at $496 \mathrm{~nm}$ and $526 \mathrm{~nm}$ which is assigned to ${ }^{2} \mathrm{~A}_{1 \mathrm{~g}}$ $\rightarrow{ }^{2} \mathrm{~B}_{2 \mathrm{~g}}$, and ${ }^{2} \mathrm{~A}_{1 \mathrm{~g}} \rightarrow{ }^{2} \mathrm{E}_{1 \mathrm{~g}}$ transition, typical for a paramagnetic $d^{7} \mathrm{Co}$ (II) configuration (Konstantinovic et al., 2003). The electronic spectra of the copper complex showed two bands at 541 and $565 \mathrm{~nm}$, with a shoulder at $595 \mathrm{~nm}$ which can be assigned to ${ }^{2} \mathrm{~B}_{2 \mathrm{~g}} \rightarrow{ }^{2} \mathrm{~A}_{1 \mathrm{~g}},{ }^{2} \mathrm{~B}_{1 \mathrm{~g}} \rightarrow{ }^{2} \mathrm{~B}_{2 \mathrm{~g}}$, and ${ }^{2} \mathrm{~B}_{1 \mathrm{~g}} \rightarrow{ }^{2} \mathrm{E}_{1 \mathrm{~g}}$ transitions (Miessler \& Tarr, 1999; Lever, 1984). The electronic spectrum of the nickel complex showed two bands at 538 and $547 \mathrm{~nm}$ which are attributed to ${ }^{1} \mathrm{~A}_{1} \mathrm{~g} \rightarrow{ }^{1} \mathrm{~A}_{2} \mathrm{~g}$ and ${ }^{1} \mathrm{~A}_{1 \mathrm{~g}} \rightarrow{ }^{2} \mathrm{~B}_{2 \mathrm{~g}}$ transistions (Cotton et al., 1999) indicating a distorted square planar geometry and is supported by the magnetic moment. Manganese complex exhibited bands at, 499, $538,547 \mathrm{~nm}$ and assigned as ${ }^{6} \mathrm{~A}_{1 \mathrm{~g}} \rightarrow{ }^{4} \mathrm{~T}_{1 \mathrm{~g}} ;{ }^{6} \mathrm{~A}_{1 \mathrm{~g}} \rightarrow{ }^{4} \mathrm{E}_{\mathrm{g}} ;{ }^{6} \mathrm{~A}_{1 \mathrm{~g}} \rightarrow{ }^{4} \mathrm{E}_{\mathrm{g}}$ respectively. The $\mathrm{Cd}$ (II) complex spectra showed no d-d transition. This is expected, since cadmium has a filled $4 d$ orbital in the ground state (Greenwood \& Earnshaw, 1997).

\subsubsection{Glycinato Complexes}

Ligand (2) exhibited absorption bands at $199 \mathrm{~nm}, 211 \mathrm{~nm}$, attributed to the $\mathrm{n} \rightarrow \pi^{*} 244 \mathrm{~nm}, \pi \rightarrow \pi^{*}$ of the carbonyl and amino moiety. A shift was observed generally for all the complexes indicating coordination. The $\mathrm{Co}$ (II) complex exhibited two bands at 511 and $820 \mathrm{~nm}$ with a shoulder at $523 \mathrm{~nm}$. These are assigned to ${ }^{2} \mathrm{~B}_{1 \mathrm{~g}} \rightarrow$ ${ }^{2} \mathrm{~A}_{1 \mathrm{~g}},{ }^{2} \mathrm{~B}_{1 \mathrm{~g}} \rightarrow{ }^{2} \mathrm{E}_{1 \mathrm{~g}}$ and ${ }^{2} \mathrm{~B}_{1 \mathrm{~g}} \rightarrow{ }^{2} \mathrm{~B}_{2 \mathrm{~g}}$ transitions respectively, typical for square planar configuration around $\mathrm{Co}(\mathrm{II})$ (Cotton et al., 1999; Konstantinovic et al., 2003). Two bands were observed in the electronic spectrum of the copper complex, at $637 \mathrm{~nm}$ and $820 \mathrm{~nm}$ which can be assigned to ${ }^{2} \mathrm{~B}_{1 \mathrm{~g}} \rightarrow{ }^{2} \mathrm{~B}_{2 \mathrm{~g}}$ and ${ }^{2} \mathrm{~B}_{1 \mathrm{~g}} \rightarrow{ }^{2} \mathrm{E}_{1 \mathrm{~g}}$ transitions (Miessler \& Tarr, 1999). The electronic spectrum of the nickel complex showed two bands at $526 \mathrm{~nm}$ and a shoulder at $541 \mathrm{~nm}$ which are attributed to ${ }^{1} \mathrm{~A}_{1 \mathrm{~g}} \rightarrow{ }^{1} \mathrm{~A}_{2 \mathrm{~g}}$ and ${ }^{1} \mathrm{~A}_{1 \mathrm{~g}} \rightarrow{ }^{2} \mathrm{~B}_{2 \mathrm{~g}}$ transistions (Cotton et al., 1999). The spectrum for the maganese complex showed transition bands at 433, 496 and $541 \mathrm{~nm}$, respectively assigned as ${ }^{6} \mathrm{~A}_{1 \mathrm{~g}} \rightarrow{ }^{4} \mathrm{~T}_{1 \mathrm{~g}} ;{ }^{6} \mathrm{~A}_{1 \mathrm{~g}} \rightarrow{ }^{4} \mathrm{E}_{\mathrm{g}} ;{ }^{6} \mathrm{~A}_{1 \mathrm{~g}} \rightarrow{ }^{4} \mathrm{E}_{\mathrm{g}}$. The $\mathrm{Cd}(\mathrm{II})$ complex spectra showed no $d-d$ transition. This is expected, since cadmium has a filled $4 d$ orbital in the ground state (Greenwood \& Earnshaw, 1997).

\subsection{Infra-red Spectra}

The IR spectral assignment of the metal complexes was achieved by comparing their vibration frequencies with those of the free ligands and literature reports of similar compounds. Relevant IR band frequencies are shown in Tables 4-5.

\subsubsection{Phenylalanine Complexes}

The bands observed for the various moieties are in close agreement with those reported for phenylalanine complexes by Saunders, 2009.

The $\mathrm{COO}^{-}$stretching frequencies of complexes of amino acids have been reported to be affected by coordination, and as such, are useful tools in the structural elucidation of amino acid complexes (Nakamoto, 1986; Pavia et al., 2001). In the free ligand, the $\mathrm{COO}^{-}$bond is symmetric and the two bond lengths are equal (3). Two bands are therefore observed, the symmetric and the asymmetric stretching frequency bands $(\mathbf{4 a}, \mathbf{4 b})$. On coordination (5), the asymmetric stretching frequency shifts to higher energy, while the symmetric stretching to lower. The absoprtion bands at $1626 \mathrm{~cm}^{-1}$ and $1566 \mathrm{~cm}^{-1}$ in the free ligand are attributed to the $\mathrm{COO}^{-}$.

The asymmetric frequency bands were shifted to higher values on coordination except in complexes of cadmium and copper. On the other hand, bathochromic shifts was observed for the symmetric bands. The N-H bending vibration band in aromatic compounds, often overlap the aromatic $\mathrm{C}=\mathrm{C}$ ring absorption band, which also appears 
in this region (Nakamoto, 2009). Consequently, a distinct $\mathrm{C}=\mathrm{C}$ band was not obtained for most of the complexes. The $-\mathrm{NH}_{2}$ stretching frequency reduced on coordination, attributable to the reduction in bond order on coordination (Nakamoto, 2009). N-H $\cdots \mathrm{O}$ interaction was also observed in all the complexes.

In complexes of amino acids, hydrogen bonding has been reported to occur between carboxyl oxygen atoms, which are not coordinated to the metal, and the amino group of the neighbouring molecule (Nakamoto, 2009; Saunders, 2009). Consequently, the $\mathrm{COO}^{-}$stretching frequencies are affected by coordination and intermolecular interactions. This was observed in all the complexes synthesized. Hydrogen atoms of the amino group interact with the uncoordinated oxygen atom of the carboxylate group, giving $\mathrm{N}-\mathrm{H}^{\cdots \cdots} \mathrm{O}$ interaction. The result of this are the sharp extended bands observed at $\sim 3340-3870 \mathrm{~cm}^{-1}$ in. Band frequencies observed at $469-472 \mathrm{~cm}^{-1}$ are assigned to (M-N) bond. The participation of the lone pairs of electrons on the $\mathrm{N}$ of the amino group in the ligand is supported by this band frequency (Osunlaja et al., 2009). New bands were observed in the region of 693-699 $\mathrm{cm}^{-1}$, indicating formation of M-O bond and support the coordination of the ligand to the central metal ions via the oxygen atom of the carboxylate group (Nakamoto, 2009).

\subsubsection{Glycine Complexes}

The glycine ligand $v_{\text {asy }}\left(\mathrm{COO}^{-}\right)$was observed at $1615 \mathrm{~cm}^{-1}$ and the $v_{\mathrm{sy}}\left(\mathrm{COO}^{-}\right)$at $1457 \mathrm{~cm}^{-1}$. Sharp extended bands were observed in the expected region. This is expected as a result of the zwitterionic nature of the ligand in the crystalline form. On coordination, hypsochromic shifts were observed for the asymmetric stretching frequencies. This is in agreement with reported literature (Nakamoto, 2009). Sharp extended bands at $\sim 3280-3870 \mathrm{~cm}^{-1}$ were also observed in all the complexes, indicating hydrogen bonding between the uncoordinated oxygen atom of the carboxyl group and the amino group of neighbouring molecule. The band frequencies at $502-530 \mathrm{~cm}^{-1}$ were assigned to (M-N) bond and those at $718-742 \mathrm{~cm}^{-1}$ to the M-O stretching.

\subsection{Magnetic Moments}

Measurements of the effective magnetic moments of coordination compounds can be used to estimate the number of unpaired electrons. The stereochemistry and bond type of the coordinated metal ion can then be determined from the information derived from it (Greenwood \& Earnshaw, 1997). The magnetic moments for some of the complexes were obtained and the results are presented in Table 5.

\subsubsection{Nickel(II) Complexes}

There is no clear cut distinction between the magnetic moments of tetrahedral and octahedral Nickel(II) complexes. This is because they both have the same number of unpaired electrons in the $d$-orbital. However, the square planar Nickel(II) complex is diamagnetic. A magnetic moment of $1.15 \mathrm{BM}$ was observed for $\mathrm{Ni}(\mathrm{phe})_{2}$. This is interpreted as an indication of a low-spin-high-spin equilibrium mixture with paramagnetic Nickel(II) species and agrees with what was reported by Woods and Patel (1994).

\subsubsection{Cobalt(II) Complexes}

The $\mathrm{Co}(\text { phe })_{2}$ complex has a magnetic moment of $2.32 \mathrm{BM}$ which indicates a square planar geometry having one unpaired electron (Greenwood \& Earnshaw, 1997).

\subsubsection{Cadmium(II) Complexes}

The magnetic moment of the Cadmium complex was zero. This value indicates that the complex has no unpaired electron. It is diamagnetic. This is expected for a $d^{10}$ system in which the $4 d$ orbital is completely filled. The value observed is in accordance to that reported on other Cadmium(II) complexes (Anacona et al., 2005).

\subsubsection{Copper(II) Complexes}

Copper coordination compounds have magnetic moments in the range of 1.9-2.2 BM, indicating that it has one unpaired electron (Greenwood \& Earnshaw, 1997). The observed magnetic moments of 1.93 BM is therefore similar and indicates a single unpaired electron as expected for a $d^{9}$ system. This is also supported by evidence from the UV-Vis spectra, indicating a square planar complex.

\subsubsection{Manganese(II) Complexes}

The Mn (II) complex, Mnphe 2 , has a high spin magnetic moment of 5.29 BM, expected for a $d^{5}$ system with five unpaired electrons. The zero Crystal Field Stabilisation Energy (CFSE) of the high-spin configuration confers no advantage of any particular stereochemistry for Mn(II) ion (Greenwood \& Earshaw, 1997). Hence magnetic moment values are unlikely to be of significance in discriminating between the metal ions in octahedral or tetrahedral field symmetries. However, the value obtained agrees well with works published for $d^{5} \mathrm{Mn}(\mathrm{II})$ systems (Anacona et al., 2005). 


\subsection{Mass Spectrum}

The low resolution electron impact (E.I) mass spectra of that of the ligands and $\mathrm{Cd}(\mathrm{phe})_{2}$ were obtained. The probable fragmentation patterns are presented in Figures 1-3 and are shown below.

\subsubsection{Phenylalanine}

A weak molecular ion $\mathrm{m} / \mathrm{z} 165,2 \%$ was observed in the mass spectrum of phenylalanine. The fragmentation pattern of the molecular ion followed three pathways, X, Y, Z. Pathway X involves the loss of the carboxylic acid radical $\mathrm{COOH}$ to give the positive ion at $\mathrm{m} / \mathrm{z} 120,57 \%$. This fragments further by rupturing of the C-N bond, leading to the loss of $\mathrm{NH}_{2}$ to give a peak at $\mathrm{m} / \mathrm{z} 103,10 \%$. Pathway Y involves the $\alpha$ bond cleavage leading to the loss of the benzylic radical to give the ion at $\mathrm{m} / \mathrm{z} 74$, the base peak. In pathway $\mathrm{Z}$ the molecular ion loses $\mathrm{m} / \mathrm{z} 74$, to give the benzylic cation at $\mathrm{m} / \mathrm{z} 91,63 \%$, with subsequent rearrangement to give the tropylium ion. The ion expels $\mathrm{C}_{2} \mathrm{H}_{2}$ (acetylene) giving the peak at $\mathrm{m} / \mathrm{z} 65,6 \%$ and this fragmentation give gives rise to a metastable ion at $65^{2} / 91=46$. The benzylic cation also fragments to give the phenyl cation $\mathrm{m} / \mathrm{z} 77,15 \%$, with subsequent extrusion of $\mathrm{C}_{2} \mathrm{H}_{2}$ to give a peak at $\mathrm{m} / \mathrm{z} 51,6.5 \%$. This is shown schematically in Figure 1 .

\subsubsection{Glycine}

The electron impact mass spectrum of the ligand, glycine did not contain the molecular ion peak. However, a prominent base peak was observed at $\mathrm{m} / \mathrm{z} 30,100 \%$. This coincides with the loss of $\mathrm{COOH}$. This is shown schematically in Figure 2.

\subsubsection{Cd(phe $)_{2}$}

The expected molecular ion was not observed. This is not unusual because the energy used in electron impact ionization has the possibility of further fragmenting the molecular ion. However, with an expected molecular ion of $\mathrm{m} / \mathrm{z} 388$ the fragmentation pattern was observed to follow two routes, $\mathrm{T}$ and U. Path T corresponds to the loss of one ligand from the molecular ion with the peak at $\mathrm{m} / \mathrm{z} 276,1 \%$. Pathway $\mathrm{U}$ agrees with the formation of a ligand as a positive ion with the observed peak at $\mathrm{m} / \mathrm{z} 164,4 \%$. The ion loses a benzylic radical leading to the formation of the ion with the peak observed at $\mathrm{m} / \mathrm{z}$ 73, which is the base peak. Further fragmentation by the lose $\mathrm{COO}$ gave a peak at $\mathrm{m} / \mathrm{z} 120,84.52 \%$. This fragments producing a tropylium ion at $\mathrm{m} / \mathrm{z} 91,83.33 \%$. This is represented schematically in Figure 3.

\subsection{In-Vitro Studies}

The synthesized compounds were screened for possible anti- bacterial and -fungi activities. The zones of inhibition were obtained against one fungus, three Gram-positive and three Gram-negative bacteria. The Gram-positive bacteria are Bacillus subtilis, NCIB 3610; Staphylococcus aureus, NCTC 6571 and Methicillin Resistant Staphylococcus aureus (MRSA), ATCC 300. The Gram-negative bacteria are Escherichia coli, NCTC 8196; Pseudomonas aeruginosa, ATCC 19429 and Proteus vulgaris, NCIB. While Candida albicans NCYC 6 the fungus. The standard used was acriflavine. The results indicated that the compounds exhibited broad spectrum activities against the bacteria and fungi strains and in some cases higher activities compared to the standard. The results obtained are presented in Tables 7 and 8 .

The results obtained indicate that the metals are contributory factors in the antimicrobial activities of the complexes. Most of the complexes irrespective of the ligand used, gave similar zones of inhibition. Pointing to the fact that donor atoms and the size of the chelate ring are similar for both ligands.

It is suggested that the lipophilic character of the coordination complexes be increased as this would enhance their ability to permeate the cell walls of the microbes. This may increase the antimicrobial activity of the compounds considerable.

\section{Conclusion}

The coordination complexes of $\mathrm{Mn}(\mathrm{II}), \mathrm{Co}(\mathrm{II}), \mathrm{Ni}(\mathrm{II}), \mathrm{Cu}(\mathrm{II}), \mathrm{Cd}(\mathrm{II})$ with two amino acids glycine and phenylalanine were synthesized and characterized. The ligands coordinated the metal ions through $\mathrm{N}$ and $\mathrm{O}$ donor atoms. A square planar geometry was proposed based on the result of the various analyses. A comparative study of the zones of inhibition indicated that chelation may increase the antimicrobial activity of biological ligands such as amino acids. Also the antimicrobial activity of the coordination compounds is also a function of the metal. 


\section{References}

Anacona, J. R., Martell, T., \& Sanchez I. (2005). Metal complexes of a new ligand derived from 2,3-quinoxalinedithiol and 2,6-bis(bromomethyl)pyridine. Chilean Chemical Society, 50(1). http://dx.doi.org/10.4067/S0717-97072005000100001

Chohan, Z. H., Arif, M., Akhtar, M. A., \& Supurean, C. T. (2006). Metal-based antibacterial and antifungal agents: synthesis, characterization, and in vitro biological evaluation of $\mathrm{Co}(\mathrm{II}), \mathrm{Cu}(\mathrm{II}), \mathrm{Ni}(\mathrm{II})$, and $\mathrm{Zn}(\mathrm{II})$ complexes with amino acid-derived compounds. Bioinorganic Chemistry and Application, 13, 83131. http://dx.doi.org/10.1155/BCA/2006/83131

Cotton, F. A., Wilkinson, G., \& Murillo, C. A. (1999). Advanced Inorganic Chemistry, $6^{\text {th }}$ ed. New York Wiley Interscience, 420, 638-648, 1355-1375.

El Husseiny A. F., Aazam E. S., \& Al Shebary J. (2008). Synthesis, characterization and antibacterial activity of Schiff-base ligand incorporating coumarin moiety and it metall complexes. Inorganic chemistry an Indian journal, 3(1), 64-68.

Greenwood, N. N., \& Earnshaw, A. (1997). Coordination compounds. In: Chemistry of the elements (2nd ed.), Oxford: Butterworth-Heinemann, 1060-1090, 1290-1326.

Komiyama, T., Igarashi, S., \& Yukawa, Y. (2008). Synthesis of polynuclear complexes with an amino acid or a peptide as a bridging ligand. Current Chemical Biology, 2(2), $122-139$. http://dx.doi.org/10.2174/187231308784220509

Konstantinovic, S., Radovanovic, C., Cakic, Z., \& Vasic, V. (2003). Synthesis and characterization of Ci(II), $\mathrm{Ni}(\mathrm{II}), \mathrm{Cu}(\mathrm{II})$ and $\mathrm{Zn}(\mathrm{II})$ complexes with 3-salicylidenehydrazono-2-indolinone. Journal of Serbian Chemical Society, 68(8/9), 641-647. http://dx.doi.org/10.2298/JSC0309641K

Kostova, I. (2006). Platinum complexes, as anticancer agents. Recent Patents on Anti-Cancer Discovery, 1, 1-22. http://dx.doi.org/10.2174/157489206775246458

Legler, A. V., Kazachenko, A. S., Kazbanov, V. I., \& Per'yanova, O. V. (2001). Synthesis and antimicrobial activity of silver complexes with arginine and glutamic acid. Pharmaceutics Chemistry Journal, 35(9), 35-36. http://dx.doi.org/10.1023/A:1014098810078

Microbiology. 6th Ed., American Society for Microbiology, Washington, DC.

Miessler, G. L., \& Tarr, D. A. (1999). Coordination compounds. In: Inorganic chemistry, $2^{\text {nd }}$ Ed. Prentice Hall: United states, 642, 315-316.

Murray, P. R., Baroon, E. J., Pfaller, M. A., Tenover F. C., \& Yolke, R. H. (1995). Manual of Clinical.

Nakamoto K. (1986). Complexes of amino acids. In: K. Nakamoto, \& S. McCarthy (Eds.), Spectroscopy and structure of metal chelate compounds. $4^{\text {th }}$ Ed.; Wiley Interscience: New York. 194-197.

Nakamoto K. (2009). Complexes of amino acids. Infraredd and raman spectroscopy of inorganic and coordination compounds: applications in coordination, organometallics and bioinorganic chemistry. John $6^{\text {th }}$ Ed.; Wiley and Sons: United states. 67-69.

Nomiya, K., \& Yokoyama, H. (2002). Synthesis, crystal structures anti antimicrobial activities of polymeric silver(I) complexes with three amino-acids [aspartic acid $\left(\mathrm{H}_{2} \mathrm{asp}\right)$, glycine (Hgly) and asparagines (Hasn)]. Journal of Chemical Society, Dalton Transaction, 2(12), 2483-2490. http://dx.doi.org/10.1039/b200684g

Nomiya, K., Takahashi, S., Noguchi, R., Nemoto, S., Takayama, T., \& Oda, M. (2000). Synthesis and characterization of water-soluble silver (I) complexes with L-histidine ( $\mathrm{H}_{2}$ his $)$ and $(s)-(-)$-2-pyrrolidone-5-carboxylic acid $\left(\mathrm{H}_{2}\right.$ pyrrld) showing a wide spectrum of effective antibacterial and antifungal activities. Crystal structures of chiral helical polymers $[\mathrm{Ag}(\mathrm{Hhis})]_{n}$ and $\left\{[\operatorname{Ag}(\operatorname{Hpyrrld})]_{2}\right\}_{n}$ in the solid state. Inorganic Chemistry, 39(15), 3301-3311. http://dx.doi.org/10.1021/ic990526o

Osunlaja A. A., Ndahil N. P., \& Ameh J. A. (2009). Synthesis, physico-chemical and antimicrobial properties of $\mathrm{Co}(\mathrm{II}), \mathrm{Ni}(\mathrm{II})$ and $\mathrm{Cu}(\mathrm{II})$ mixed-ligand complexes of dimethylglyoxime - Part I. African Journal of Biotechnology, 8(1), 4-11.

Pavia, D. L., Lampmar, G. L., \& Kriz, G. S. (2001). Introductory Spectroscopy, a guide for student of organic chemistry. $3^{\text {rd }}$ Ed.; Brooks/ Cole: United States.79. 
Saunders, D. L. (2009). Ph.D thesis Isolation of Lead-Amino Acid and Mercury-Amino Acid Complexes with Characterization in the Solid State, the Solution State, and the Gas Phase Dalhousie University Department of Chemistry Halifax, Nova Scotia, 116-119.

The authors are grateful to Dr Oyetunji of the Chemistry Department, University of Botswana, Botwana and Dr. (Mrs) Ogunlusi of the Department of Chemistry Obafemi Awolowo University, Ile-Ife, Nigeria for their assistance in obtaining the magnetic susceptibility measurements and mass spectra obtained at the Chemistry Department University of Botswana, Botswana.

Woods J. A. O., \& Patel K. S. (1994). Nickel complexes of some 3-substituted -2,4-petanedione and their adducts with 2,2'-bipyridine and 1,10-phenanthroline. Synthsis Reactivity in Inorganic Metal-Organic Chemistry, 24(9), 1557-1571. http://dx.doi.org/10.1080/00945719408002580

Zhang, C. X., \& Lippard, S. J. (2003). New metal complexes as potential therapeutics. Current Opinion in Chemical Biology, 7(4), 481-489. http://dx.doi.org/10.1016/S1367-5931(03)00081-4

Table 1. Some physical properties of the complexes

\begin{tabular}{lcccc}
\hline Compound & Empirical Formulae & Colour & M.P/D.T ( $\left.{ }^{\circ} \mathrm{C}\right)$ & Yield (\%) \\
\hline $\mathrm{Co}(\text { gly })_{2}$ & $\mathrm{Co}\left(\mathrm{C}_{2} \mathrm{H}_{4} \mathrm{O}_{2} \mathrm{~N}\right)$ & Pink & $260(\mathrm{~d})$ & 61.6 \\
$\mathrm{Cu}(\text { gly })_{2}$ & $\mathrm{Cu}\left(\mathrm{C}_{2} \mathrm{H}_{4} \mathrm{O}_{2} \mathrm{~N}\right)$ & Turquoise blue & $209-211(\mathrm{~d})$ & 67.4 \\
$\mathrm{Mn}(\text { gly })_{2}$ & $\mathrm{Mn}\left(\mathrm{C}_{2} \mathrm{H}_{4} \mathrm{O}_{2} \mathrm{~N}\right)$ & White & $202-204(\mathrm{~d})$ & 74.4 \\
$\mathrm{Ni}(\text { gly })_{2}$ & $\mathrm{Ni}\left(\mathrm{C}_{2} \mathrm{H}_{4} \mathrm{O}_{2} \mathrm{~N}\right)$ & Green & $201(\mathrm{~d})$ & 60.2 \\
$\mathrm{Cd}(\text { gly })_{2}$ & $\mathrm{Cd}\left(\mathrm{C}_{2} \mathrm{H}_{4} \mathrm{O}_{2} \mathrm{~N}\right)$ & White & $201(\mathrm{~d})$ & 72.7 \\
$\mathrm{Co}(\text { phe })_{2}$ & $\mathrm{Co}\left(\mathrm{C}_{9} \mathrm{H}_{10} \mathrm{O}_{2} \mathrm{~N}\right)$ & Pink & $231-232$ & 84.3 \\
$\mathrm{Cu}(\text { phe })_{2}$ & $\mathrm{Cu}\left(\mathrm{C}_{9} \mathrm{H}_{10} \mathrm{O}_{2} \mathrm{~N}\right)$ & Blue & $191-193$ & 67.2 \\
$\mathrm{Mn}(\text { phe })_{2}$ & $\mathrm{Mn}\left(\mathrm{C}_{9} \mathrm{H}_{10} \mathrm{O}_{2} \mathrm{~N}\right)$ & White & $244-247$ & 69.6 \\
$\mathrm{Ni}(\text { phe })_{2}$ & $\mathrm{Ni}\left(\mathrm{C}_{9} \mathrm{H}_{10} \mathrm{O}_{2} \mathrm{~N}\right)$ & Green & $226(\mathrm{~d})$ & 72.8 \\
$\mathrm{Cd}(\text { phe })_{2}$ & $\mathrm{Cd}\left(\mathrm{C}_{9} \mathrm{H}_{10} \mathrm{O}_{2} \mathrm{~N}\right)$ & White & $198(\mathrm{~d})$ & 62.4 \\
\hline
\end{tabular}

Table 2. Electronic spectra bands(nm) for the glycinato-complexes (1:2)

\begin{tabular}{lcccc}
\hline Compound & Band I & Band II & Band III & d-d \\
\hline Glycine & 199 & 211 & 244 & \\
$\mathrm{Cu}(\text { gly })_{2}$ & 202 & 235 & 385,391 & 637shld, 667, 820, 832shld \\
$\mathrm{Cd}(\text { gly })_{2}$ & 196 & 265 & 296 & - \\
$\mathrm{Co}(\text { gly })_{2}$ & 205 & 223 & 241,313 & 484 shld, 511, 523shld \\
$\mathrm{Mn}(\mathrm{gly})_{2}$ & 235 & 283 & 313,373 & 433, 496shld, 526, 541 \\
$\mathrm{Ni}(\mathrm{gly})_{2}$ & 205 & 214 & 241 & 433, 496shld, 526, 541 shld \\
\hline
\end{tabular}

Shld $=$ shoulder . 
Table 3. Electronic spectra bands (nm) for the phenylalanito-complexes and ligand

\begin{tabular}{lccccc}
\hline Compound & Band I & Band II & Band III & Band IV & d-d \\
\hline Phenylalanine & 196 & 217 & 232 & 268 & $433,496,514,538$ \\
$\mathrm{Cu}(\text { phe })_{2}$ & 196 & 208 & 223 & 238 & 526 shld, 541, 565, 595shld \\
$\mathrm{Cd}(\text { phe })_{2}$ & 199 & 241 & - & - & $103,610,511,069$ \\
$\mathrm{Ni}(\text { phe })_{2}$ & - & 217 & 232 & 262 & $433,496,538,547$ shld \\
$\mathrm{Co}(\text { phe })_{2}$ & 196 & 220 & 238 & 265 & 433,484 shld, 496, 526shld \\
$\mathrm{Mn}($ phe $)$ & 205 & 214 & 232 & 310 & $433,499,538,547$ shld \\
\hline
\end{tabular}

Shld $=$ shoulder.

Table 4. Relevant Infrared frequencies for the glycinato-complexes and ligand

\begin{tabular}{lcccccc}
\hline Band & Glycine (ligand) & $\mathrm{Cu}(\mathrm{gly})_{2}$ & $\mathrm{Cd}(\mathrm{gly})_{2(\mathrm{~cm}-1)}$ & $\mathrm{Ni}(\mathrm{gly})_{2}$ & $\mathrm{Co}(\mathrm{gly})_{2}$ & $\mathrm{Mn}(\mathrm{gly})_{2}$ \\
\hline$v_{\mathrm{s}}\left(\mathrm{NH}_{2}\right)$ & $3119 \mathrm{br}$ & $3252 \mathrm{br}$ & $3110 \mathrm{br}$ & $3243 \mathrm{br}$ & $3267 \mathrm{br}$ & $3154 \mathrm{br}$ \\
$v_{\text {asy. }}\left(\mathrm{COO}^{-}\right)$ & $1615 \mathrm{~s}$ & $1636 \mathrm{w}$ & $1641 \mathrm{~s}$ & $1646 \mathrm{~m}$ & $1626 \mathrm{~m}$ & $1634 \mathrm{~m}$ \\
$v_{\text {sy. }}\left(\mathrm{COO}^{-}\right)$ & & $1506 \mathrm{sh}$ & $1458 \mathrm{~m}$ & - & $1406 \mathrm{~m}$ & $1458 \mathrm{~m}$ \\
$v(\mathrm{M}-\mathrm{N})$ & $518 \mathrm{~s}$ & $552 \mathrm{sh}$ & $555 \mathrm{sh}$ & $571 \mathrm{w}$ & $531 \mathrm{vs}$ \\
$v(\mathrm{M}-\mathrm{O})$ & $665 \mathrm{sh}$ & $696 \mathrm{~s}$ & $773 \mathrm{sh}$ & $721 \mathrm{w}$ & $683 \mathrm{sh}$ \\
\hline
\end{tabular}

Keys: gly = glycine $\mathrm{w}=$ weak; $\mathrm{m}=$ medium; $\mathrm{s}=$ strong; $\mathrm{vs}=$ very strong; br $=$ broad; $\mathrm{sh}=$ sharp.

Table 5. Relevant Infrared frequencies for the phenylalanito-complexes and ligand

\begin{tabular}{lcccccc}
\hline Band & Phe & $\mathrm{Cu}(\mathrm{phe})_{2}$ & $\mathrm{Cd}(\mathrm{phe})_{2}\left(\mathrm{~cm}^{-1}\right)$ & $\mathrm{Ni}(\mathrm{phe})_{2}$ & $\mathrm{Co}(\mathrm{phe})_{2}$ & $\mathrm{Mn}(\mathrm{phe})_{2}$ \\
\hline$v_{\mathrm{s}}\left(\mathrm{NH}_{2}\right)$ & $3454 \mathrm{br}$ & $3301 \mathrm{sh}$ & $3404 \mathrm{br}$ & $3356,3282 \mathrm{sh}$ & $3357 \mathrm{br}$ & $3380,3285 \mathrm{br}$ \\
$v_{\text {asy }}\left(\mathrm{COO}^{-}\right)$ & $1626 \mathrm{~m}$ & $1616 \mathrm{w}$ & $1616 \mathrm{~s}$ & $1635 \mathrm{~s}$ & $1635 \mathrm{sh}$ & $1716 \mathrm{~m}$ \\
$v_{\text {sy. }}\left(\mathrm{COO}^{-}\right)$ & $1566 \mathrm{~m}$ & $1503 \mathrm{~s}$ & $1414 \mathrm{sh}$ & $1457 \mathrm{~s}$ & $1457 \mathrm{~s}$ & $1456 \mathrm{~s}$ \\
$v(\mathrm{M}-\mathrm{N})$ & & $534 \mathrm{sh}$ & $524 \mathrm{sh}$ & $521 \mathrm{vs}$ & $529 \mathrm{vs}$ & $520 \mathrm{~m}$ \\
$v(\mathrm{M}-\mathrm{O})$ & $675 \mathrm{sh}$ & $693 \mathrm{~s}$ & $693 \mathrm{~s}$ & $699 \mathrm{~m}$ & $678 \mathrm{~m}$ \\
\hline
\end{tabular}

Keys: phe $=d l$-phenylalanine; $\mathrm{w}=$ weak; $\mathrm{m}=$ medium; $\mathrm{s}=$ strong; $\mathrm{vs}=$ very strong; $\mathrm{br}=$ broad; $\mathrm{sh}=$ sharp. 
Table 6. Magnetic moment for some of the complexes

\begin{tabular}{lc}
\hline COMPOUND & $\mu_{\text {eff }}(\mathrm{BM})$ \\
\hline $\mathrm{Cu}(\text { phe })_{2}$ & 1.93 \\
$\mathrm{Co}(\text { phe })_{2}$ & 2.32 \\
$\mathrm{Ni}(\text { phe })_{2}$ & 1.15 \\
$\mathrm{Cd}(\text { phe })_{2}$ & 0 \\
$\mathrm{Mn}(\text { phe })_{2}$ & 5.29 \\
\hline
\end{tabular}

Table 7. Results of zone of inhibition (mm) for glycinato-complexes

\begin{tabular}{lccccccc}
\hline Microorganisms & $\mathrm{Gly}$ & $\mathrm{Cu}(\mathrm{gly})_{2}$ & $\mathrm{Cd}(\mathrm{gly})_{2}$ & $\mathrm{Ni}(\mathrm{gly})_{2}$ & $\mathrm{Co}(\mathrm{gly})_{2}$ & $\mathrm{Mn}(\mathrm{gly})_{2}$ & $\mathrm{C}$ \\
\hline E. coli(-) & 6 & 15 & 8 & 6 & 6 & 11 & 20 \\
P. aeruginosa(-) & 6 & 6 & 6 & 6 & 7 & 8 & 6 \\
S. aureus(+) & 6 & 6 & 8 & 6 & 6 & 8 & 20 \\
$P$. vulgaris(-) & 6 & 6 & 6 & 6 & 6 & 11 & 15 \\
B. subtilis(+) & 6 & 6 & 8 & 6 & 6 & 16 & 6 \\
MRSA(+) & 6 & 6 & 6 & 6 & 6 & 6 & 6 \\
C. Albicans & 6 & 6 & 15 & 16 & 20 & 13 & 19 \\
\hline
\end{tabular}

Table 8. Results of zone of inhibition (mm) for phenylalanito-complexes

\begin{tabular}{lccccccc}
\hline Microorganisms & $\mathrm{Phe}$ & $\mathrm{Cu}(\mathrm{phe})_{2}$ & $\mathrm{Cd}(\mathrm{phe})_{2}$ & $\mathrm{Ni}(\mathrm{phe})_{2}$ & $\mathrm{Co}(\mathrm{phe})_{2}$ & $\mathrm{Mn}(\mathrm{phe})_{2}$ & $\mathrm{C}$ \\
\hline E. coli(-) & 6 & 14 & 6 & 8 & 6 & 11 & 20 \\
P. aeruginosa(-) & 6 & 6 & 6 & 8 & 6 & 8 & 6 \\
S. aureus(+) & 6 & 24 & 6 & 6 & 6 & 8 & 20 \\
$P$. vulgaris(-) & 6 & 6 & 6 & 6 & 6 & 11 & 15 \\
B. subtilis(+) & 6 & 6 & 6 & 8 & 6 & 16 & 6 \\
MRSA(+) & 6 & 6 & 6 & 6 & 6 & 6 & 6 \\
C. Albicans & 14 & 6 & 6 & 6 & 6 & 13 & 19 \\
\hline
\end{tabular}




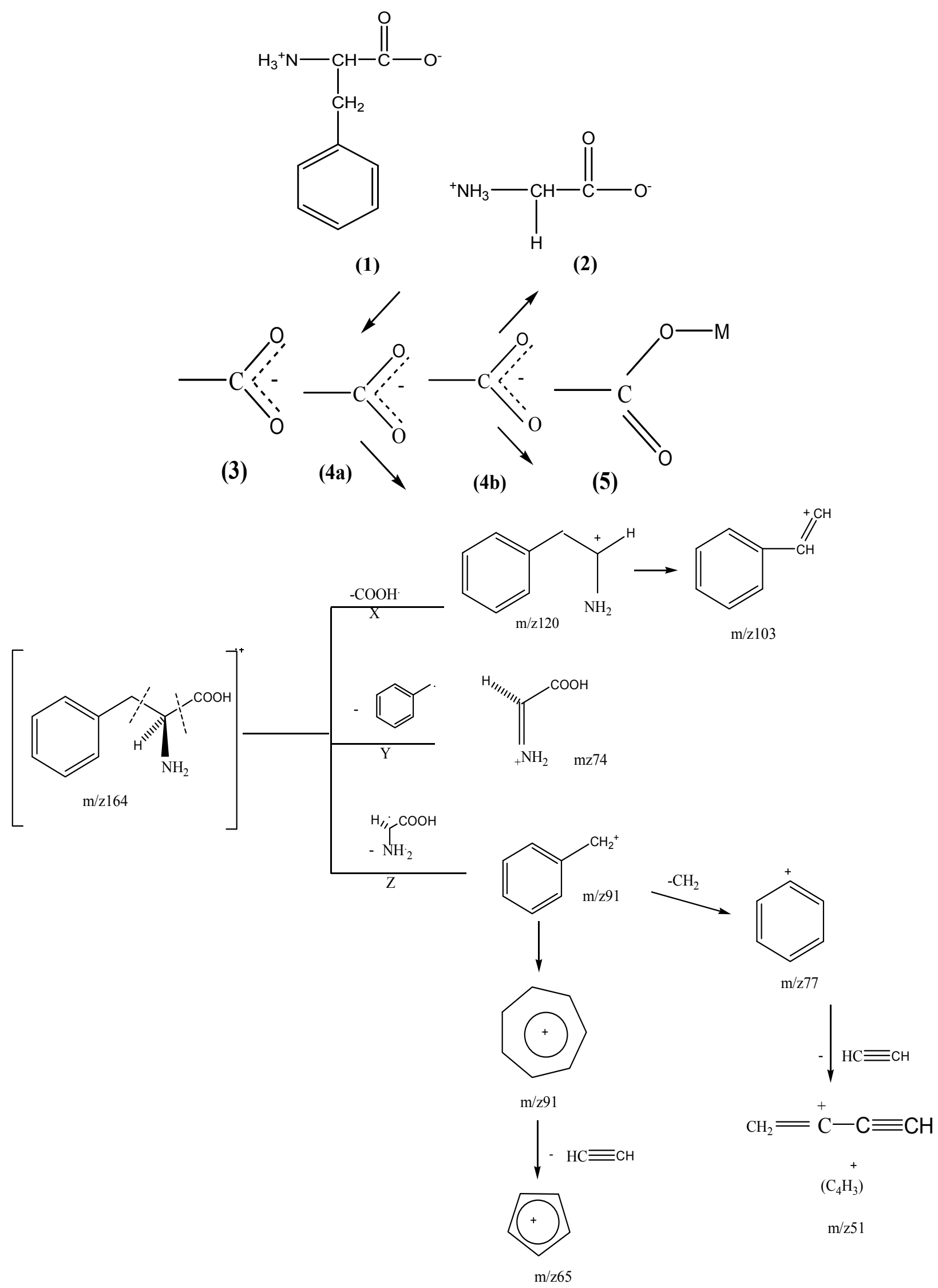

Figure 1. Proposed fragmentation pattern of phenylalanine 


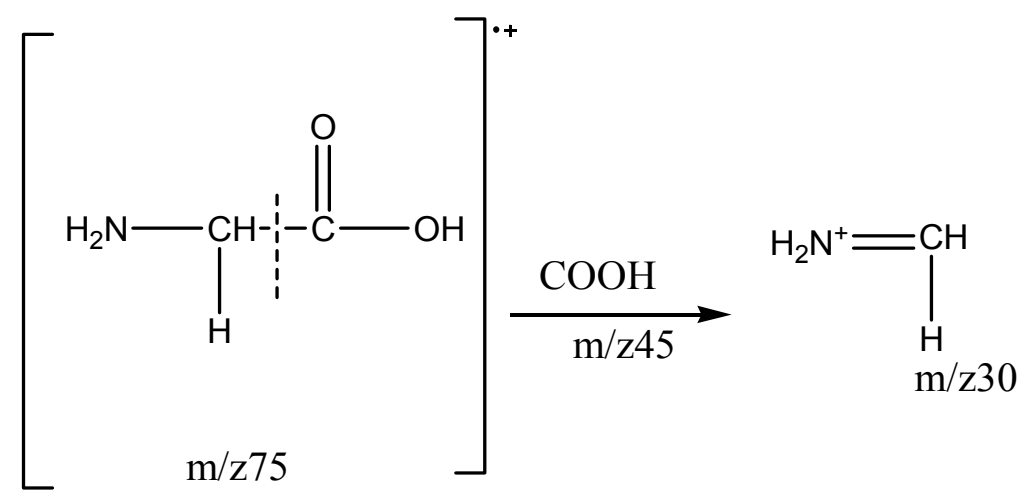

Figure 2. Proposed fragmentation pattern of glycine

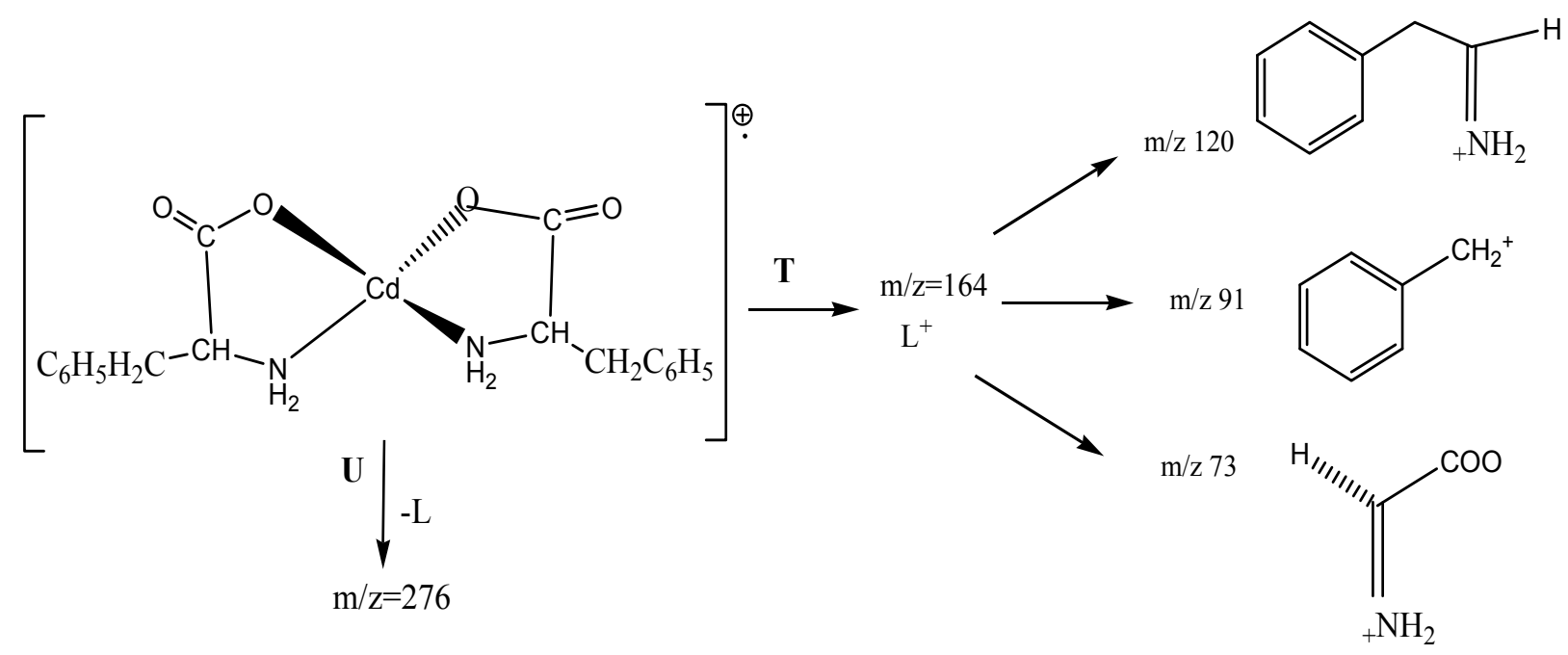

Figure 3. Proposed fragmentation pattern of $\mathrm{Cd}(\mathrm{phe})_{2}$ 